\title{
Evaluation of USA and Canadian Research Vessel Surveys for Sea Scallops (Placopecten magellanicus) on Georges Bank
}

\author{
Fredric M. Serchuk and Susan E. Wigley \\ National Marine Fisheries Service, Northeast Fisheries Center \\ Woods Hole, Massachusetts, USA 02543
}

\begin{abstract}
Independent research vessel surveys of the sea scallop resource on the northeastern part of Georges Bank were conducted annually by the USA and Canada during 1982-84. Despite differences between the USA and Canadian surveys in sampling design, statistically-comparable estimates of relative abundance, population size composition, and recruitment levels were obtained from the two surveys in each year. Four potential factors contributing to this concordance of results are identified and evaluated with respect to survey design considerations, sampling intensity and future survey activities. Because the information from the USA and Canadian surveys appears to be the same, there would be virtually no loss in accuracy or precision if survey responsibilities were shared on an alternate-year basis. Moreover, since survey ship time is costly, a considerable saving of expense would ensue to both countries from this arrangement.
\end{abstract}

\section{Introduction}

Since the mid-1970's, the USA and Canada have independently conducted annual research vessel surveys of sea scallop (Placopecten magellanicus (Gmelin)) populations on Georges Bank to evaluate trends in abundance, size and age compositions, and recruitment. Results from both series of surveys have been used to assess resource and fishery status and to forecast future stock conditions (Serchuk et al., 1979, MS 1982; Jamieson et al., MS 1981; Robert et al., MS 1982; Serchuk, MS 1983; Mohn et al., MS 1984, MS 1985; Serchuk and Wigley, MS 1984). Scientific advice, developed from the survey analyses, has been rendered to resource managers in both nations to impart an understanding of the biological basis of the sea scallop fisheries.

Although similar sampling gears are used in USA and Canadian surveys, the sampling designs differ. The USA survey employs a stratified-random design with scallop-sampling strata based on water depth and latitude, whereas the Canadian survey uses a stratified-random scheme with sampling strata based on commercial catch-per-unit-effort contours derived prior to each survey.

During 1982-84, separate but seasonally concurrent (summer) annual scallop surveys were conducted by each country on the northern edge and peak region of Georges Bank. In all 3 years of surveys, identifical types of data on scallop catch and size composition were recorded. Copies of the survey logsheets were exchanged between countries, affording access of all survey information to both USA and Canadian scient- ists. Hence, it was possible to undertake comparative analyses to evaluate the consistency and accuracy of results from the two survey series.

In this paper, the findings of these analyses are presented and the comparability of estimates of sea scallop abundance, size composition and recruitment from USA and Canadian surveys in 1982-84 are examined. Spatial patterns in the distribution and abundance of scallops, inferred from both survey series, are also assessed and discussed in relation to survey design considerations.

\section{Materials and Methods}

\section{Research vessels and sampling gear}

USA scallop surveys during 1982-84 were conducted with the research vessel Albatross IV $(57 \mathrm{~m}$ long, 1,130 horsepower, 988 gross metric tons). This vessel had been used in all previous USA scallop surveys. Sampling was performed with a standard $8 \mathrm{ft}$ $(2.44 \mathrm{~m})$ wide commercial sea scallop dredge equipped with a 2 inch $(5.1 \mathrm{~cm})$ ring bag and a 1.5 inch $(3.8 \mathrm{~cm})$ mesh polypropylene liner to retain small scallops. Detailed gear specifications were reported by Serchuk and Smolowitz (MS 1980).

Canadian scallop surveys were conducted with the research vessel $E$. E. Prince ( $40 \mathrm{~m}$ long, 600 horsepower, 406 gross metric tons) (Halliday and Koeller, 1981). Tows were made with a standard $8 \mathrm{ft}(2.44 \mathrm{~m})$ wide New Bedford scallop dredge equipped with a 3 inch $(7.62 \mathrm{~cm})$ ring bag and a 1.5 inch $(3.8 \mathrm{~cm})$ mesh polypropylene liner. 


\section{Sampling designs}

In both USA and Canadian scallop surveys during 1982-84, different stratified-random sampling designs were employed, and the stratification schemes were based on different variables. In the USA surveys, offshore areas from 27 to $110 \mathrm{~m} \mathrm{(15} \mathrm{to} 60 \mathrm{fm}$ ) are stratified into geographical zones based on depth and latitude (Fig. 1), with four depth zones being covered (27-46, $46-55,55-73$ and $73-110 \mathrm{~m}$ ). The survey area on the northeastern part of Georges Bank (latitude $40^{\circ} 48^{\prime}$ to $42^{\circ} 09^{\prime} \mathrm{N}$, longitude $65^{\circ} 55^{\prime}$ to $68^{\circ} 28^{\prime} \mathrm{W}$ ), encompassing 4,472 square nautical miles $\left(\mathrm{nm}^{2}\right)$, is divided into 10 sampling strata. Sampling stations are allotted to strata in proportion to stratum area and are assigned randomly within each stratum. Additional randomlyselected stations are frequently assigned to those strata in which either commercial fishing activity or sea scallop concentrations are known to occur in order to provide more precise estimates of relative abundance.

The stratified design of the Canadian scallop surveys is based on geographic contours of commercial catch-per-unit-effort (CPUE) by the Canadian scallop fleet (Jamieson and Chandler, MS 1980; Robert et al., MS 1982; Mohn et al., MS 1985). Prior to each annual survey, isopleth maps of Canadian CPUE values are generated from the previous 11 months of fishing activity. CPUE strata are established by grouping 1-min square (1' latitude $\times 1$ ' longitude) CPUE values into four categories (very low, low, medium and high) and constructing closed-curve contours of the geographi-

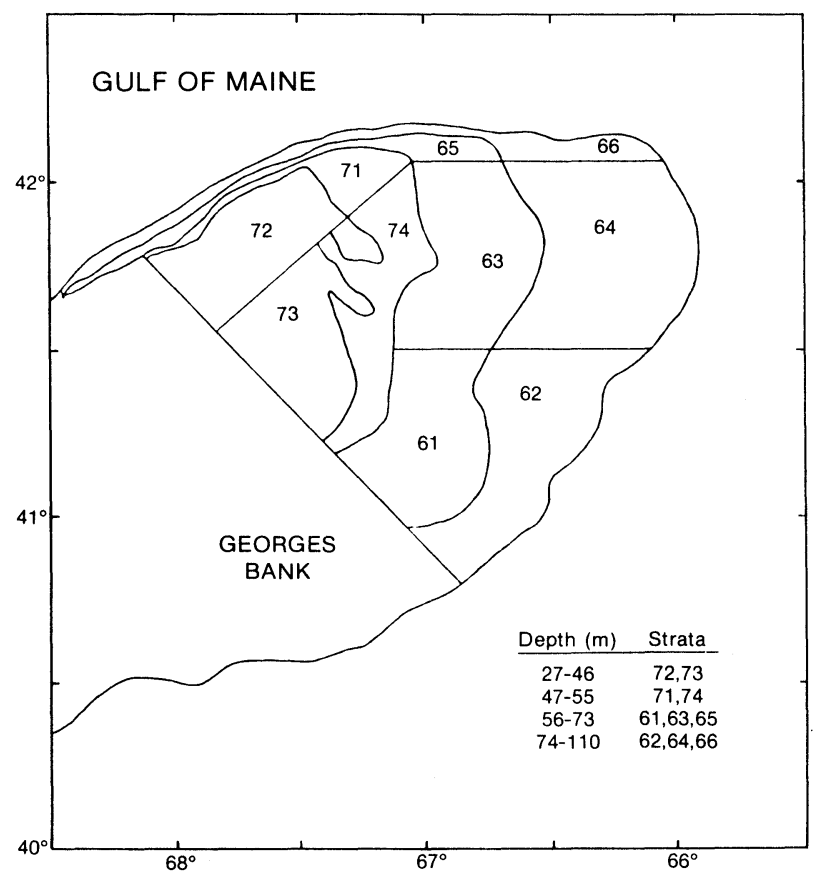

Fig. 1. Sampling strata used in USA research vessel surveys for sea scallops on northeastern Georges Bank since 1979. (Total area encompassed by the 10 strata is $4,472 \mathrm{~nm}^{2}$.) cal area subsumed within each CPUE stratum. CPUE levels $(\mathrm{kg} / \mathrm{chm})$ are expressed as catch $(\mathrm{kg})$ divided by the product of number of crew members (c), hours fished $(\mathrm{h})$ and meter width of dredge $(\mathrm{m})$. The four categories for the $1982-84$ surveys were $<0.2,0.2-0.5$, $0.5-1.0$ and $>1.0$. Survey sampling stations are allotted to the three lower CPUE strata in proportion to their relative area. The highest CPUE stratum is sampled much more heavily, with about $40 \%$ of the survey stations allocated to this region (Robert and Jamieson, MS 1984). Within strata, stations are randomly selected from an array of potential sampling locations spaced $2.2 \mathrm{~km}$ apart. Because the areal distribution of commercial catch rates change from year to year, the area enclosed by each CPUE stratum (i.e. the "weighting factor" in a stratified estimate) varies from year to year.

The area covered by the Canadian surveys on the northeastern part of Georges Bank in 1982-84 (4,112 $\mathrm{nm}^{2}$ ) was slightly smaller than that covered in the USA surveys. Boundaries of the Canadian survey area ranged from $41^{\circ} 18^{\prime}$ to $42^{\circ} 12^{\prime} \mathrm{N}$ latitude and from $65^{\circ} 48^{\prime}$ to $67^{\circ} 30^{\prime} \mathrm{W}$ longitude. Depth of sampling varied from 44 to $187 \mathrm{~m}$ (24 to $102 \mathrm{fm}$ ).

\section{Sampling and catch processing procedures}

Nearly identical sampling and catch processing procedures were used during the USA and Canadian surveys in 1982-84. The principal differences between the surveys were in the duration and speed of the "standard tow" at each station. In the USA surveys, the survey dredge was towed for 15 minutes at 3.5 knots with a 3:1 wire scope. In the Canadian surveys, the survey dredge was hauled for 10 minutes at 4.0 knots with a 3:1 wire scope. Hence, the mean towing distance per station was $0.875 \mathrm{~nm}$ in the USA surveys and 0.667 $\mathrm{nm}$ in the Canadian surveys. In all other respects, the survey procedures were similar. After each tow, the catch was sorted into biological and trash components. All live scallops were enumerated and shell height measurements (by $5-\mathrm{mm}$ intervals) were recorded. Occasionally, subsampling was necessary when large quantities of scallops were caught. All bycatches of finfish and other invertebrates were also enumerated and measured. Trash portions were measured by volume and the substrate type and composition were noted. The sampling dredge and liner were inspected routinely and repaired or replaced as appropriate. Hydrographic and navigational data were recorded at each sampling location, including distance towed over bottom from a Doppler speed log (USA surveys only).

\section{Data analysis}

Relative abundance indices for sea scallops were calculated in terms of average number per tow (both actual and with In $(x+1)$ transformation) and average 
meat weight per tow for each of the 10 USA survey strata on the northeastern part of Georges Bank (Fig. 1 ), and in terms of stratified mean catch per tow (number and meat weight) for the region as a whole, following the procedures of Cochran (1977, page 91) and Pennington and Grosslein (MS 1978). Survey indices were derived for prerecruit scallops ( $<70 \mathrm{~mm}$ shell height), recruited or commercial-sized scallops ( $>70$ $\mathrm{mm}$ shell height), and total scallops (all sizes) per tow. Mean meat-weight values were obtained by applying to the shell height frequency distributions the shell height- meat weight equation for sea scallops which has been developed from the USA research vessel survey data from Georges Bank:

In $W=-11.7656+3.1693 \ln H \quad(N=5,863, r=0.98)$,

where $W$ is meat weight $(\mathrm{g}), \mathrm{H}$ is shell height $(\mathrm{mm}), \mathrm{N}$ is number of specimens, $r$ is correlation coefficient, and In refers to natural logarithms.

Comparison of Canadian data with USA survey results was facilitated by poststratifying Canadian sampling stations into the USA strata (Fig. 2). The Canadian catch data were then standardized into USA survey equivalents to account for the difference in mean distance of tow between USA and Canadian standard tows (i.e. 0.875 and $0.667 \mathrm{~nm}$ respectively). Standardization was accomplished by expanding the Canadian catch data from each tow by a factor of 1.312 .
Mean catch-per-tow values from the standardized Canadian survey data were subsequently calculated for each stratum and for the entire survey area. Size frequency data from both the USA and Canadian surveys were summarized for each stratum and for the entire region, and were then expressed as standardized mean number per tow of scallops per shell-height interval.

Canadian tows located outside the USA survey strata boundaries (i.e. $>110 \mathrm{~m}$ ) were excluded from all analyses. Equally, for those strata in which no Canadian tows occurred (stratum 73 in 1982, 1983 and 1984, and stratum 72 in 1982 and 1983 (Table 1, Fig. 2)), no comparisons could be made with USA survey results. Hence, the USA data from these strata were also excluded from subsequent analyses.

Comparisons between USA and Canadian estimates of relative scallop abundance for each stratum in each year were accomplished by using a two-sample analysis of variance (Student's t-test). In several cases, the sample variances were heterogeneous and approximate t-tests (Sokal and Rohlf, 1981; page 441) were performed to test the equality of the USA and Canadian mean catch-per-tow values. Similar testing procedures were employed in comparing the mean depth of sampling in each stratum for the two survey series. Differences in USA and Canadian shell-height distributions
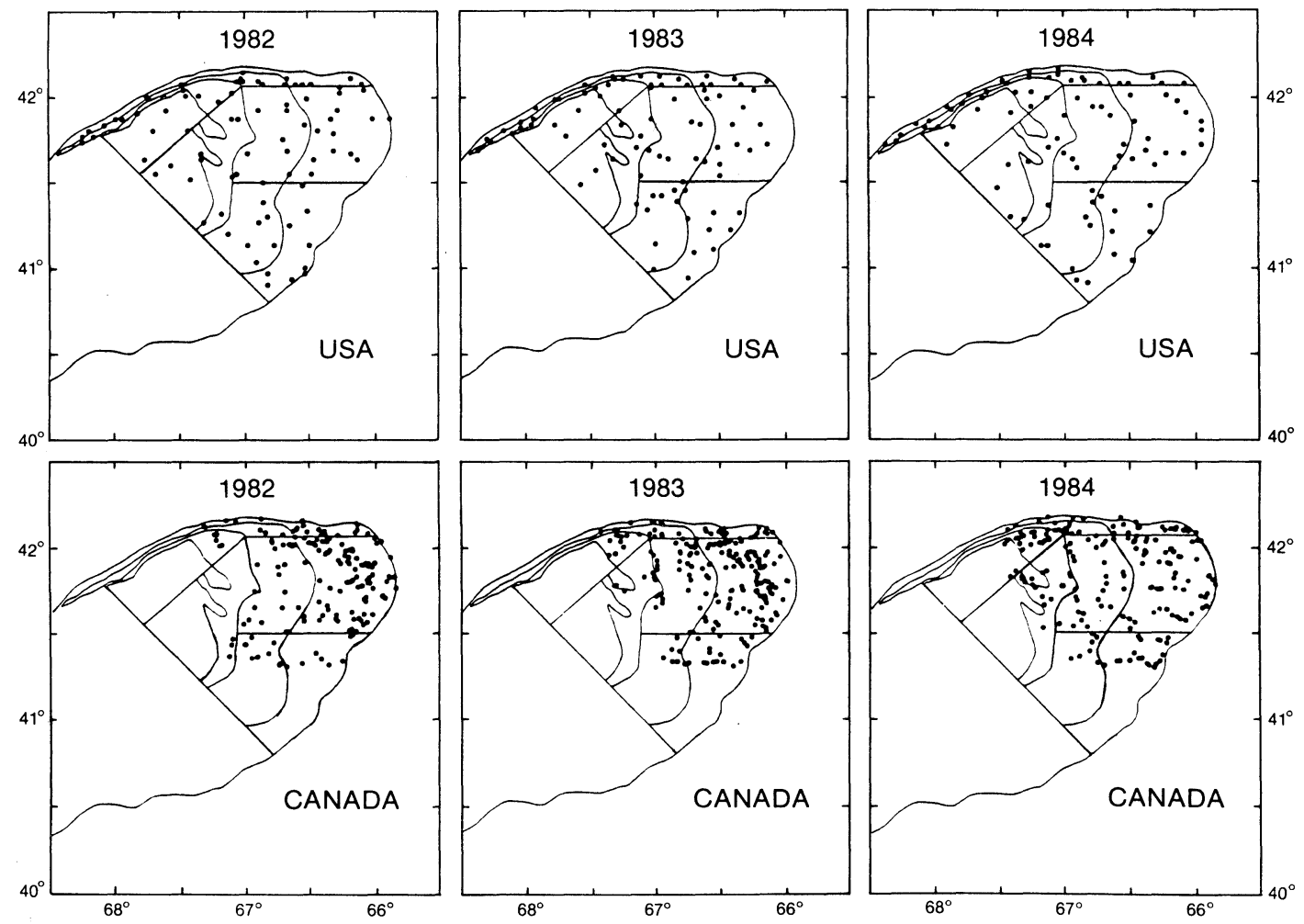

Fig. 2. Locations of tows during USA and Canadian research vessel surveys for sea scallops on northeastern Georges Bank in 1982-84. (Locations of Canadian tows outside the USA sampling strata boundaries, i.e. $>110 \mathrm{~m}$, are not depicted.) 
were evaluated by stratum (mean number-per-tow at height) and for the region (stratified mean numberper-tow at height) by using the Kolmogorov-Smirnov two-sample test (Sokal and Rohlf, 1981, page 443). Spatial patterns in scallop abundance and recruitment were inferred from differences in mean catch-per-tow indices and size distributions among strata from both the USA and Canadian survey results.

\section{Results}

\section{Sampling intensity and overall catch}

A total of 814 tows from the USA and Canadian scallop surveys of northeastern Georges Bank in 1982-84 were analyzed (235 USA tows, and 579 Canadian tows). Sampling averaged 78 tows per year (range 75-82) in the USA surveys and 193 tows per year (range 165-225) in the Canadian surveys (Table 1). Annual survey sampling intensity (stratum area divided by number of tows) varied between 51 and $55 \mathrm{~nm}^{2}$ in the USA surveys and between 18 and $24 \mathrm{~nm}^{2}$ in the Canadian surveys (Table 2). In all 3 years, the number of tows in the Canadian surveys was more than double that in the USA surveys. In 1983, Canadian sampling intensity ( 1 tow per $18 \mathrm{~nm}^{2}$ ) was nearly three times greater than USA sampling intensity (1 tow per 51 $\left.\mathrm{nm}^{2}\right)$.

Sampling intensities per stratum in the USA surveys ranged from a high of 1 tow per $11 \mathrm{~nm}^{2}$ (stratum 65 in 1983) to 1 tow per $126 \mathrm{~nm}^{2}$ (stratum 72 in 1984) in the USA surveys, and from 1 tow per $9 \mathrm{~nm}^{2}$ (stratum 64 in 1983 and stratum 71 in 1984) to 1 tow per $126 \mathrm{~nm}^{2}$ (stratum 72 in 1984) in the Canadian surveys (Table 2). The largest difference in allotted sampling effort between the USA and Canadian surveys occurred in 1983 in stratum 64 (Fig. 2), where Canada made 110 tows and the USA only 14 tows (Table 1), about an eightfold difference in sampling intensity. During all 3 years, more tows were accomplished in stratum 64 during the Canadian surveys than in any other stratum.

In 1982-84, sea scallop catches ranged from 0 to 5,560 individuals per tow in the USA surveys and from 0 to 8,428 scallops $(6,424$ unadjusted) per standardized

TABLE 1. Numbers of tows by sampling strata and other information relevant to the USA and Canadian research vessel surveys for sea scallops on the northeastern part of Georges Bank, 1982-84.

\begin{tabular}{|c|c|c|c|c|c|c|c|c|c|c|c|c|c|c|c|c|}
\hline \multirow[b]{3}{*}{ Year } & \multirow[b]{3}{*}{ Country } & \multirow[b]{3}{*}{ Month } & \multicolumn{2}{|c|}{ Mean tow parameters } & \multirow{2}{*}{\multicolumn{10}{|c|}{$\begin{array}{c}\text { Numbers of tows within USA sea scallop } \\
\text { sampling strata (see Fig. 1) }\end{array}$}} & \multirow{3}{*}{$\begin{array}{l}\text { Total } \\
\text { tows }\end{array}$} & \multirow{3}{*}{$\begin{array}{l}\text { Anal- } \\
\text { yzed } \\
\text { tows }\end{array}$} \\
\hline & & & \multirow{2}{*}{$\begin{array}{l}\text { Duration } \\
\text { (min) }\end{array}$} & \multirow{2}{*}{$\begin{array}{c}\text { Speed } \\
\text { (knots) }\end{array}$} & & & & & & & & & & & & \\
\hline & & & & & 61 & 62 & 63 & 64 & 65 & 66 & 71 & 72 & 73 & $\overline{74}$ & & \\
\hline \multirow[t]{2}{*}{1982} & USA & Jul & 15 & 3.5 & 7 & 9 & 10 & 14 & 12 & 14 & 4 & 5 & 5 & 5 & 85 & 75 \\
\hline & Canada & Aug-Sep & 10 & 4.0 & 10 & 8 & 21 & 90 & 3 & 23 & 6 & - & - & 4 & 185 & 165 \\
\hline \multirow[t]{2}{*}{1983} & USA & Aug & 15 & 3.5 & 7 & 9 & 10 & 14 & 15 & 14 & 4 & 4 & 4 & 5 & 86 & 78 \\
\hline & Canada & Aug & 10 & 4.0 & 5 & 19 & 40 & 110 & 9 & 27 & 10 & - & - & 5 & 225 & 225 \\
\hline \multirow[t]{2}{*}{1984} & USA & Aug & 15 & 3.5 & 7 & 9 & 10 & 14 & 14 & 14 & 5 & 4 & 4 & 5 & 86 & 82 \\
\hline & Canada & Aug & 10 & 4.0 & 9 & 18 & 29 & 56 & 12 & 25 & 17 & 4 & - & 19 & 189 & 189 \\
\hline
\end{tabular}

a USA tows in strata 72 and 73 (with no Canadian tows) were excluded from subsequent comparative analyses.

TABLE 2. Sampling intensity (stratum area divided by number of tows) by stratum during USA and Canadian research vessel surveys for sea scallops on the northeastern part of Georges Bank, 1982-84. (USA data for stratum 73 excluded because there were no Canadian tows.)

\begin{tabular}{|c|c|c|c|c|c|c|c|c|c|}
\hline \multirow{3}{*}{$\begin{array}{l}\text { Stratum } \\
\text { number }\end{array}$} & \multirow{3}{*}{$\begin{array}{c}\text { Stratum } \\
\text { area } \\
\left(\mathrm{nm}^{2}\right)\end{array}$} & & & \multicolumn{6}{|c|}{ Sampling intensity ( $\mathrm{nm}^{2} /$ tow $)$} \\
\hline & & \multicolumn{2}{|c|}{ Depth range } & \multicolumn{2}{|c|}{1982} & \multicolumn{2}{|c|}{1983} & \multicolumn{2}{|c|}{1984} \\
\hline & & $(\mathrm{fm})$ & $(\mathrm{m})$ & USA & Canada & USA & Canada & USA & Canada \\
\hline 61 & 576 & $30-40$ & $55-73$ & 82 & 58 & 82 & 115 & 82 & 64 \\
\hline 62 & 701 & $40-60$ & $73-110$ & 78 & 88 & 78 & 37 & 78 & 39 \\
\hline 63 & 694 & $30-40$ & $55-73$ & 69 & 33 & 69 & 17 & 69 & 24 \\
\hline 64 & 988 & $40-60$ & $73-110$ & 71 & 11 & 71 & 9 & 71 & 18 \\
\hline 65 & 164 & $30-40$ & $55-73$ & 14 & 55 & 11 & 18 & 12 & 14 \\
\hline 66 & 266 & $40-60$ & $73-110$ & 19 & 12 & 19 & 10 & 19 & 11 \\
\hline 71 & 146 & $25-30$ & $46-55$ & 37 & 24 & 37 & 15 & 29 & 9 \\
\hline $72^{a}$ & 504 & $15-25$ & $27-46$ & - & - & - & - & 126 & 126 \\
\hline 74 & 433 & $25-30$ & $46-55$ & 87 & 108 & 87 & 87 & 87 & 23 \\
\hline Total & 4,472 & $15-60$ & $27-110$ & - & - & - & - & 55 & 24 \\
\hline Total & 3,968 & $25-60$ & $46-110$ & 53 & 24 & 51 & 18 & - & - \\
\hline
\end{tabular}

a USA data for stratum 72 in 1982 and 1983 were excluded because there were no Canadian tows for comparison. 
tow in the Canadian surveys. Over the 3 years, a total of 208,284 scallops were sampled $(51,585$ by USA, and 156,699 by Canada), weighing 1.12 metric tons (meat weight). The largest individual catches during the USA surveys occurred in stratum 66 in 1982 and $1983(1,243$ and 1,433 scallops respectively) and in stratum 64 in 1984 (5,560 scallops). The largest individual catches during the Canadian surveys occurred in stratum 64 $(1,659$ in $1982,1,939$ in 1983 and 8,428 in 1984).

\section{Sampling locations}

Station (tow) locations during the USA and Canadian scallop surveys are depicted, within USA sampling strata, in Fig. 2. Geographical overlap between the surveys was greatest in the northeastern areas of Georges Bank (strata 63, 64 and 66). Canadian coverage of the more westerly and southwesterly areas of the Bank was more sporadic than in the USA surveys. Few Canadian stations occurred in the southern portions of strata 61 and 62 , and no Canadian tows were made in the western extensions of strata 65,66 and 71 . At face value, these within-stratum differences in USA and Canadian spatial sampling distributions implied that abundance indices from the two surveys would differ significantly due to the patchy nature of scallop distribution.

\section{Relative abundance}

Relative abundance and biomass indices from the USA and Canadian sea scallop surveys in 1982-84 are summarized in Tables 3 and 4 . Nearly parallel estimates of stratified mean number-per-tow and mean weight-per-tow for the northern edge and peak areas of Georges Bank were obtained in each year. Percentage differences between USA and Canadian annual abundance estimates (stratified mean number-pertow) were minor: $7 \%$ in 1982 (118 vs 110 ), $35 \%$ in 1983 (95 vs 128), and $5 \%$ in 1984 (348 vs 331). Percentage differences between annual USA and Canadian weight-per-tow indices were also modest: $8 \%$ in 1982 ( 1.18 vs 1.09 ), $34 \%$ in 1983 (0.82 vs 1.10 ), and $14 \%$ in 1984 ( 1.13 vs 0.99). USA and Canadian catch-per-tow estimates were also remarkably similar for prerecruit scallops $(<70 \mathrm{~mm})$ and for recruited $(\geqslant 70 \mathrm{~mm}) \mathrm{scal}-$ lops. The largest percentage difference in prerecruit estimates was $22 \%$ in the 1983 surveys (54.4 vs 66.2

TABLE 3. Relative abundance indices (standardized mean number and mean meat weight per tow) and mean shell height of sea scallops by stratum from USA and Canadian research vessel surveys on the northeastern part of Georges Bank, 1982-84. (Abundance indices are given for prerecruit $(<70 \mathrm{~mm}$ shell height) and recruited ( $\geqslant 70 \mathrm{~mm}$ ) sea scallops separately.)

\begin{tabular}{|c|c|c|c|c|c|c|c|c|c|c|c|c|c|c|c|c|c|}
\hline \multirow[b]{3}{*}{ Year } & \multirow{3}{*}{$\begin{array}{l}\text { Stratum } \\
\text { number }\end{array}$} & \multirow{2}{*}{\multicolumn{2}{|c|}{$\begin{array}{l}\text { Number } \\
\text { of tows }\end{array}$}} & \multicolumn{6}{|c|}{ Mean number of scallops per tow } & \multicolumn{6}{|c|}{ Mean meat weight $(\mathrm{kg})$ of scallops per tow ${ }^{\mathrm{a}}$} & \multirow{2}{*}{\multicolumn{2}{|c|}{$\begin{array}{c}\text { Mean shell } \\
\text { height }(\mathrm{mm})\end{array}$}} \\
\hline & & & & \multicolumn{2}{|c|}{$<70 \mathrm{~mm}$} & \multicolumn{2}{|c|}{$\geqslant 70 \mathrm{~mm}$} & \multicolumn{2}{|c|}{ Total } & \multicolumn{2}{|c|}{$<70 \mathrm{~mm}$} & \multicolumn{2}{|c|}{$\geqslant 70 \mathrm{~mm}$} & \multicolumn{2}{|c|}{ Total } & & \\
\hline & & $\overline{U S A}$ & Canada & USA & Canada & USA & Canada & USA & Canada & $\overline{U S A}$ & Canada & USA & Canada & USA & Canada & & Canada \\
\hline \multirow[t]{9}{*}{1982} & 61 & 7 & 10 & 0.1 & 0.0 & 11.3 & 7.1 & 11.4 & 7.1 & $<0.01$ & 0.00 & 0.40 & 0.34 & 0.40 & 0.34 & 121.3 & 136.8 \\
\hline & 62 & 9 & 8 & 7.9 & 5.8 & 58.3 & 58.8 & 66.2 & 64.6 & 0.03 & 0.02 & 0.92 & 0.84 & 0.95 & 0.86 & 90.6 & 89.7 \\
\hline & 63 & 10 & 21 & 37.5 & 42.0 & 25.5 & 57.5 & 63.0 & 99.5 & 0.11 & 0.13 & 0.45 & 0.91 & 0.56 & 1.04 & 74.1 & 79.8 \\
\hline & 64 & 14 & 90 & 78.1 & 81.9 & 159.4 & 122.1 & 237.5 & 204.0 & 0.21 & 0.24 & 2.16 & 1.55 & 2.37 & 1.79 & 78.9 & 75.5 \\
\hline & 65 & 12 & 3 & 122.3 & 25.0 & 114.1 & 116.3 & 236.4 & 141.3 & 0.34 & 0.08 & 1.29 & 1.35 & 1.63 & 1.43 & 69.9 & 81.8 \\
\hline & 66 & 14 & 23 & 167.1 & 107.8 & 130.7 & 161.8 & 297.8 & 269.6 & 0.54 & 0.41 & 1.66 & 1.79 & 2.20 & 2.20 & 70.9 & 75.7 \\
\hline & 71 & 4 & 6 & 24.3 & 70.7 & 62.1 & 76.0 & 86.3 & 146.7 & 0.05 & 0.20 & 0.90 & 1.18 & 0.95 & 1.38 & 80.8 & 76.3 \\
\hline & 74 & 5 & 4 & 2.8 & 0.0 & 7.4 & 0.0 & 10.2 & 0.0 & 0.01 & 0.00 & 0.15 & 0.00 & 0.16 & 0.00 & 87.7 & - \\
\hline & Overall $^{\mathrm{b}}$ & 75 & 165 & 44.9 & 39.6 & 72.6 & 70.4 & 117.5 & 110.0 & 0.13 & 0.13 & 1.05 & 0.96 & 1.18 & 1.09 & 78.2 & 78.6 \\
\hline \multirow[t]{9}{*}{1983} & 61 & 7 & 5 & 1.3 & 0.0 & 9.7 & 4.0 & 11.0 & 4.0 & $<0.01$ & 0.00 & 0.35 & 0.24 & 0.35 & 0.24 & 115.1 & 148.0 \\
\hline & 62 & 9 & 19 & 60.4 & 29.2 & 44.6 & 35.2 & 105.0 & 64.4 & 0.06 & 0.03 & 0.81 & 0.82 & 0.87 & 0.85 & 64.4 & 79.3 \\
\hline & 63 & 10 & 40 & 14.1 & 36.8 & 25.5 & 30.1 & 39.6 & 66.9 & 0.04 & 0.09 & 0.47 & 0.54 & 0.51 & 0.63 & 84.8 & 73.4 \\
\hline & 64 & 14 & 110 & 94.1 & 113.5 & 62.3 & 107.8 & 156.4 & 221.3 & 0.16 & 0.17 & 1.15 & 1.54 & 1.31 & 1.71 & 67.8 & 67.3 \\
\hline & 65 & 15 & 9 & 197.3 & 375.7 & 47.7 & 68.9 & 245.0 & 444.6 & 0.36 & 0.61 & 0.75 & 1.13 & 1.11 & 1.74 & 57.3 & 54.7 \\
\hline & 66 & 14 & 27 & 114.3 & 96.5 & 105.6 & 216.3 & 219.9 & 312.8 & 0.11 & 0.15 & 1.39 & 2.48 & 1.50 & 2.63 & 62.3 & 73.4 \\
\hline & 71 & 4 & 10 & 14.8 & 100.0 & 17.6 & 68.9 & 32.3 & 168.9 & 0.03 & 0.21 & 0.52 & 1.01 & 0.55 & 1.22 & 85.0 & 68.1 \\
\hline & 74 & 5 & 5 & 11.2 & 6.6 & 17.8 & 29.0 & 29.0 & 35.6 & 0.04 & 0.02 & 0.27 & 0.75 & 0.31 & 0.77 & 81.6 & 101.0 \\
\hline & Overall $^{\mathrm{b}}$ & 78 & 225 & 54.4 & 66.2 & 40.8 & 62.0 & 95.2 & 128.2 & 0.09 & 0.11 & 0.73 & 0.98 & 0.82 & 1.10 & 67.9 & 69.5 \\
\hline \multirow[t]{10}{*}{1984} & 61 & 7 & 9 & 5.3 & 0.2 & 13.0 & 5.0 & 18.3 & 5.2 & 0.01 & $<0.01$ & 0.52 & 0.29 & 0.53 & 0.29 & 105.2 & 142.2 \\
\hline & 62 & 9 & 18 & 75.2 & 89.2 & 29.9 & 39.2 & 105.1 & 128.4 & 0.08 & 0.10 & 0.59 & 0.55 & 0.67 & 0.65 & 56.5 & 54.9 \\
\hline & 63 & 10 & 29 & 22.2 & 61.8 & 17.2 & 11.1 & 39.4 & 72.9 & 0.06 & 0.11 & 0.36 & 0.18 & 0.42 & 0.29 & 75.0 & 55.5 \\
\hline & 64 & 14 & 56 & 1165.9 & 1041.4 & 131.4 & 107.6 & 1297.3 & 1149.0 & 1.07 & 1.29 & 1.82 & 1.28 & 2.89 & 2.57 & 42.7 & 46.2 \\
\hline & 65 & 14 & 12 & 179.8 & 341.3 & 121.6 & 164.8 & 301.4 & 506.1 & 0.34 & 0.51 & 1.21 & 1.58 & 1.55 & 2.09 & 61.9 & 57.6 \\
\hline & 66 & 14 & 25 & 211.0 & 269.8 & 121.9 & 96.2 & 332.9 & 366.0 & 0.33 & 0.36 & 1.50 & 1.18 & 1.83 & 1.54 & 59.7 & 54.3 \\
\hline & 71 & 5 & 17 & 13.6 & 49.0 & 33.2 & 30.6 & 46.8 & 79.6 & 0.03 & 0.08 & 0.61 & 0.41 & 0.64 & 0.49 & 84.6 & 63.9 \\
\hline & 72 & 4 & 4 & 0.3 & 0.3 & 15.0 & 12.0 & 15.3 & 12.3 & $<0.01$ & $<0.01$ & 0.37 & 0.27 & 0.37 & 0.27 & 105.9 & 105.5 \\
\hline & 74 & 5 & 19 & 7.4 & 0.4 & 15.0 & 6.5 & 22.4 & 6.9 & 0.02 & $<0.01$ & 0.29 & 0.22 & 0.31 & 0.22 & 85.5 & 117.1 \\
\hline & Overall $^{\mathrm{b}}$ & 82 & 189 & 293.8 & 283.9 & 54.0 & 47.0 & 347.8 & 330.9 & 0.30 & 0.36 & 0.83 & 0.63 & 1.13 & 0.99 & 46.7 & 48.9 \\
\hline
\end{tabular}

a Mean meat weights were derived from application of the shell height-meat weight relationship (see text) to the sea scallop size frequencies.

b Overall means are stratified values, i.e. weighted by strata areas. 
TABLE 4. Actual and transformed mean catches (numbers) of sea scallops, with standard deviations (SD) and coefficients of variations $(C V=100 \times$ $\mathrm{SD} /$ Mean), by stratum from USA and Canadian research vessel surveys on the northeastern part of Georges Bank, $1982-84$.

\begin{tabular}{|c|c|c|c|c|c|c|c|c|c|c|c|c|c|c|c|}
\hline \multirow[b]{3}{*}{ Year } & \multirow{3}{*}{$\begin{array}{l}\text { Stratum } \\
\text { number }\end{array}$} & \multirow{2}{*}{\multicolumn{2}{|c|}{$\begin{array}{l}\text { Number } \\
\text { of tows }\end{array}$}} & \multicolumn{6}{|c|}{ Actual untransformed number-per-tow } & \multicolumn{6}{|c|}{ Number-per-tow transformed by $\ln (x+1)$} \\
\hline & & & & \multicolumn{2}{|c|}{ Mean } & \multicolumn{2}{|c|}{ SD } & \multicolumn{2}{|c|}{$\mathrm{CV}$} & \multicolumn{2}{|c|}{ Mean } & \multicolumn{2}{|c|}{ SD } & \multicolumn{2}{|c|}{$\mathrm{CV}$} \\
\hline & & $\overline{U S A}$ & Canada & USA & Canada & USA & Canada & USA & Canada & USA & Canada & $\overline{U S A}$ & Canada & $\overline{U S A}$ & Canada \\
\hline \multirow[t]{9}{*}{1982} & 61 & 7 & 10 & 11.4 & 7.1 & 11.8 & 9.2 & 104 & 130 & 2.078 & 1.286 & 1.142 & 1.400 & 55 & 109 \\
\hline & 62 & 9 & 8 & 66.2 & 64.6 & 65.4 & 78.4 & 99 & 121 & 3.856 & 3.773 & 0.876 & 0.925 & 23 & 25 \\
\hline & 63 & 10 & 21 & 63.0 & 99.5 & 126.9 & 195.0 & 201 & 196 & 1.886 & 2.655 & 2.221 & 2.331 & 118 & 88 \\
\hline & 64 & 14 & 90 & 237.5 & 204.0 & 282.4 & 285.6 & 119 & 140 & 4.584 & 4.515 & 1.701 & 1.482 & 37 & 33 \\
\hline & 65 & 12 & 3 & 236.4 & 141.3 & 351.5 & 97.0 & 149 & 69 & 4.291 & 4.812 & 1.701 & 0.649 & 40 & 14 \\
\hline & 66 & 14 & 23 & 297.8 & 269.6 & 397.3 & 358.0 & 133 & 133 & 4.513 & 4.759 & 1.975 & 1.678 & 44 & 35 \\
\hline & 71 & 4 & 6 & 86.3 & 146.7 & 77.4 & 48.0 & 90 & 33 & 3.475 & 4.956 & 2.373 & 0.295 & 69 & 6 \\
\hline & 74 & 5 & 4 & 10.2 & 0.0 & 17.9 & 0.0 & 176 & - & 1.433 & 0.000 & 1.556 & 0.000 & 109 & - \\
\hline & Overall ${ }^{a}$ & 75 & 165 & 117.5 & 110.0 & 22.1 & 12.9 & 18.8 & 11.7 & 3.218 & 3.142 & 0.209 & 0.133 & 6.5 & 4.2 \\
\hline \multirow[t]{9}{*}{1983} & 61 & 7 & 5 & 11.0 & 4.0 & 14.0 & 2.7 & 127 & 69 & 1.712 & 1.478 & 1.457 & 0.590 & 85 & 40 \\
\hline & 62 & 9 & 19 & 105.0 & 64.4 & 149.7 & 46.6 & 143 & 72 & 3.815 & 3.850 & 1.587 & 0.924 & 42 & 24 \\
\hline & 63 & 10 & 40 & 39.6 & 66.9 & 58.1 & 118.9 & 147 & 178 & 2.015 & 2.680 & 2.193 & 1.939 & 109 & 72 \\
\hline & 64 & 14 & 110 & 156.4 & 221.3 & 271.5 & 281.7 & 174 & 127 & 3.944 & 4.780 & 1.682 & 1.270 & 43 & 27 \\
\hline & 65 & 15 & 9 & 245.0 & 444.6 & 257.9 & 440.6 & 105 & 99 & 4.385 & 5.618 & 2.054 & 1.067 & 47 & 19 \\
\hline & 66 & 14 & 27 & 219.9 & 312.8 & 412.2 & 365.4 & 188 & 117 & 3.571 & 5.143 & 2.127 & 1.261 & 60 & 25 \\
\hline & 71 & 4 & 10 & 32.3 & 168.9 & 33.9 & 175.1 & 105 & 104 & 2.985 & 4.830 & 1.246 & 0.763 & 42 & 16 \\
\hline & 74 & 5 & 5 & 29.0 & 35.6 & 60.4 & 30.7 & 208 & 86 & 1.629 & 2.861 & 2.012 & 1.794 & 124 & 63 \\
\hline & Overall ${ }^{\mathrm{a}}$ & 78 & 225 & 95.2 & 128.2 & 22.1 & 11.2 & 23.2 & 8.7 & 2.965 & 3.620 & 0.233 & 0.122 & 7.9 & 3.4 \\
\hline \multirow[t]{10}{*}{1984} & 61 & 7 & 9 & 18.3 & 5.2 & 23.0 & 6.2 & 126 & 119 & 2.313 & 1.308 & 1.264 & 1.153 & 55 & 88 \\
\hline & 62 & 9 & 18 & 105.1 & 128.4 & 105.8 & 118.0 & 101 & 92 & 4.324 & 4.580 & 0.858 & 0.756 & 20 & 17 \\
\hline & 63 & 10 & 29 & 39.4 & 72.9 & 64.3 & 245.1 & 163 & 336 & 1.857 & 1.515 & 2.205 & 2.153 & 119 & 142 \\
\hline & 64 & 14 & 56 & 1297.3 & 1149.0 & 1858.5 & 1587.1 & 143 & 138 & 5.707 & 5.823 & 2.396 & 2.146 & 42 & 37 \\
\hline & 65 & 14 & 12 & 301.4 & 506.1 & 398.9 & 810.8 & 132 & 160 & 4.277 & 5.594 & 2.172 & 1.033 & 51 & 19 \\
\hline & 66 & 14 & 25 & 332.9 & 366.0 & 621.0 & 446.2 & 187 & 122 & 4.435 & 4.696 & 1.753 & 2.242 & 40 & 48 \\
\hline & 71 & 5 & 17 & 46.8 & 79.6 & 35.0 & 115.0 & 75 & 144 & 3.196 & 3.582 & 1.142 & 1.429 & 36 & 40 \\
\hline & 72 & 4 & 4 & 15.3 & 12.3 & 13.4 & 8.0 & 88 & 65 & 2.507 & 2.288 & 0.885 & 1.075 & 35 & 47 \\
\hline & 74 & 5 & 19 & 22.4 & 6.9 & 40.7 & 8.4 & 182 & 122 & 1.628 & 1.420 & 2.021 & 1.240 & 124 & 87 \\
\hline & Overall $^{\mathrm{a}}$ & 82 & 189 & 347.8 & 330.9 & 110.5 & 48.7 & 31.8 & 14.7 & 3.490 & 3.405 & 0.223 & 0.128 & 6.4 & 3.8 \\
\hline
\end{tabular}

${ }^{a}$ Overall means and standard deviations are stratified values, i.e. weighted bv strata areas.

scallops/tow; 0.09 vs $0.11 \mathrm{~kg} / \mathrm{tow})$, while the largest difference in weight-per-tow estimates for recruited scallops was $34 \%$ (0.73 vs $0.98 \mathrm{~kg} / \mathrm{tow}$ in 1983). On a stratum basis, only about $20 \%$ of the 150 pairs of USA and Canadian catch-per-tow estimates for 1982-84 differed by as much as $100 \%$ (Table 3 ). In many of these cases, however, absolute differences in the indices were very small.

For the non-transformed abundance estimates (Table 4), coefficients of variation on a stratum basis were large, ranging between 75 and $208 \%$ for the USA surveys and between 33 and $336 \%$ for the Canadian surveys. Little consistency was apparent between sample size (number of tows) and the resultant coefficients of variation. For the overall region, annual coefficients of variation associated with the Canadian nontransformed abundance indices were 40-60\% lower than those from the USA surveys. Over the 3 years, the mean coefficients of variation for these indices from the USA and Canadian surveys were 24.6 and $11.7 \%$ respectively, indicating that proportional changes in abundance of less than about $\pm 50 \%$ and $\pm 25 \%$ respectively would normally not be detected with high probability (i.e. $P=0.05$ ).
The In $(x+1)$ transformed abundance estimates from the USA and Canadian surveys exhibited much less variability than the corresponding nontransformed values. Stratum coefficients of variation ranged between 20 and $124 \%$ in the USA surveys and between 6 and 142\% in the Canadian surveys. Almost all of the transformed coefficients of variation were one-quarter to one-half as large as their respective non-transformed values, implying a significant improvement in relative precision by using the transformed data. On an absolute basis, however, there was little improvement in detecting proportional changes in abundance, as the retransformed confidence bands were about as large as the non-transformed confidence intervals (about $+50 \%$ for USA estimates and $\pm 30 \%$ for Canadian estimates).

Paired comparisions of abundance indices from USA and Canadian surveys were generally not significantly different (Table 5). No statistical differences $(P>0.05)$ were detected between USA and Canadian mean catch-per-tow values for any stratum in the 1982 and 1984 surveys. In the 1983 surveys, only the actual (non-transformed) abundance estimates for stratum 71 and the transformed estimates for strata 64,66 , and 
TABLE 5. Results of two-sample analysis of variance (Student's t-test) comparing sea scallop abundance indices (actual and transformed) and mean depth per tow by stratum from USA and Canadian surveys on northeastern Georges Bank, 1982-84. The last column contains Kolmogorov-Smirnov (K-S) two-sample test results from comparison of distributions of scallops in the USA and Canadian survey catches. ( ${ }^{*}$ indicates $\mathrm{P}<0.05 ;{ }^{* *}$ indicates $\left.\mathrm{P}<0.01\right)$.

\begin{tabular}{|c|c|c|c|c|c|c|c|c|c|c|c|}
\hline \multirow[b]{2}{*}{ Year } & \multirow{2}{*}{$\begin{array}{l}\text { Stratum } \\
\text { number }\end{array}$} & \multicolumn{3}{|c|}{$\begin{array}{l}\text { Actual untranformed } \\
\text { mean number per tow }\end{array}$} & \multicolumn{3}{|c|}{$\begin{array}{l}\text { Transformed In }(x+1) \\
\text { mean number per tow }\end{array}$} & \multicolumn{3}{|c|}{$\begin{array}{c}\text { Mean depth (fm) } \\
\text { per tow }^{\mathrm{a}}\end{array}$} & \multirow{2}{*}{$\begin{array}{l}\text { Size } \\
\text { frequency } \\
\text { K-S test }{ }^{\mathrm{a}}\end{array}$} \\
\hline & & USA & Canada & $t_{s}$ & USA & Canada & $t_{s}$ & USA & Canada & $t_{s}$ & \\
\hline \multirow[t]{8}{*}{1982} & 61 & 11.4 & 7.1 & 0.85 & 2.078 & 1.286 & 1.23 & 36.0 & 36.8 & 0.57 & 0.34 \\
\hline & 62 & 66.2 & 64.6 & 0.05 & 3.856 & 3.773 & 0.19 & 46.7 & 48.8 & 1.06 & 0.12 \\
\hline & 63 & 63.0 & 99.5 & 0.54 & 1.886 & 2.655 & 0.87 & 35.4 & 36.2 & 0.67 & 0.20 \\
\hline & 64 & 237.5 & 204.0 & 0.41 & 4.584 & 4.515 & 0.16 & 45.6 & 47.4 & 1.29 & 0.12 \\
\hline & 65 & 236.4 & 141.3 & 0.45 & 4.291 & 4.812 & 0.51 & 31.9 & 37.3 & $2.37^{\star}$ & $0.35^{\star \star}$ \\
\hline & 66 & 297.8 & 269.6 & 0.22 & 4.513 & 4.759 & 0.40 & 44.4 & 46.6 & 1.09 & $0.17^{\star \star}$ \\
\hline & 71 & 86.3 & 146.7 & 1.54 & 3.475 & 4.956 & $(1.24)$ & 26.5 & 25.4 & 1.82 & $0.20^{\star}$ \\
\hline & 74 & 10.2 & 0.0 & $(1.27)$ & 1.433 & 0.000 & $(2.06)$ & 26.8 & 28.5 & 1.37 & - \\
\hline \multirow[t]{8}{*}{1983} & 61 & 11.0 & 4.0 & $(1.29)$ & 1.712 & 1.478 & 0.34 & 37.3 & 37.6 & 0.28 & 0.70 \\
\hline & 62 & 105.0 & 64.4 & $(0.80)$ & 3.815 & 3.850 & 0.07 & 47.8 & 47.4 & 0.21 & $0.31^{\star \star *}$ \\
\hline & 63 & 39.6 & 66.9 & $(1.04)$ & 2.015 & 2.680 & 0.94 & 36.8 & 36.7 & 0.11 & 0.25 \\
\hline & 64 & 156.4 & 221.3 & 0.81 & 3.944 & 4.780 & $2.23^{\star}$ & 45.4 & 47.3 & 1.75 & 0.10 \\
\hline & 65 & 245.0 & 444.6 & 1.41 & 4.385 & 5.618 & 1.66 & 35.2 & 34.6 & 0.55 & 0.10 \\
\hline & 66 & 219.9 & 312.8 & 0.74 & 3.571 & 5.143 & $(2.54)^{\star}$ & 48.4 & 48.1 & 0.12 & $0.26^{\star *}$ \\
\hline & 71 & 32.3 & 168.9 & $(2.36)^{\star}$ & 2.985 & 4.830 & $3.43^{\star \star}$ & 28.0 & 26.4 & 2.07 & $0.26^{\star}$ \\
\hline & 74 & 29.0 & 35.6 & 0.22 & 1.629 & 2.861 & 1.02 & 30.6 & 30.0 & 0.34 & $0.41^{\star \star}$ \\
\hline \multirow[t]{9}{*}{1984} & 61 & 18.3 & 5.2 & $(1.46)$ & 2.313 & 1.308 & 1.66 & 38.4 & 38.3 & 0.07 & 0.49 \\
\hline & 62 & 105.1 & 128.4 & 0.50 & 4.324 & 4.580 & 0.79 & 47.6 & 50.7 & $2.76^{\star}$ & 0.08 \\
\hline & 63 & 39.4 & 72.9 & $(0.67)$ & 1.857 & 1.515 & 0.43 & 36.3 & 36.0 & 0.26 & $0.47^{\star \star}$ \\
\hline & 64 & 1297.3 & 1149.0 & 0.30 & 5.707 & 5.823 & 0.18 & 47.8 & 48.1 & 0.22 & $0.31^{\star \star *}$ \\
\hline & 65 & 301.4 & 506.1 & $(0.80)$ & 4.277 & 5.594 & $(2.02)$ & 34.0 & 32.2 & 1.60 & $0.19^{\star \star}$ \\
\hline & 66 & 332.9 & 366.0 & 0.19 & 4.435 & 4.696 & 0.38 & 46.7 & 50.1 & $(2.31)^{\star}$ & $0.15^{\star \star}$ \\
\hline & 71 & 46.8 & 79.7 & $(1.03)$ & 3.196 & 3.582 & 0.50 & 27.2 & 26.7 & 0.41 & $0.34^{\star *}$ \\
\hline & 72 & 15.3 & 12.3 & 2.45 & 2.507 & 2.288 & 0.31 & 22.8 & 24.3 & 0.46 & 0.22 \\
\hline & 74 & 22.4 & 7.0 & $(0.84)$ & 1.628 & 1.420 & 0.29 & 31.6 & 30.4 & 0.98 & 0.58 \\
\hline
\end{tabular}

a Statistical tests were performed with formulae in Sokal and Rohlf (1981): pages 226 and 411 for $t$-test ( $t_{s}$ ), and page 443 for K-S test. Values in parentheses are approximate t-test results, because F-test results indicated sample variances to be heterogeneous.

71 were statistically significant $(P<0.05)$. Of these, only the transformed estimates for stratum 71 were significantly different at the level of $P=0.01$. In none of the 3 years did USA and Canadian overall abundance estimates (actual or transformed) differ statistically from one another $(P>0.05)$.

The similarity in USA and Canadian results implies that both surveys sampled the same populations of scallops in each year. As previously noted, however, the geographical distributions of USA and Canadian sampling stations within strata were not identical. To evaluate whether spatial differences in locations of USA and Canadian tows resulted in different depths (within strata) being sampled, mean depth-per-tow in the two survey series was examined (Table 5). In only three instances during the 3 years (stratum 65 in 1982, and strata 62 and 66 in 1984) were significant differences detected between the mean depths sampled in the USA and Canadian surveys $(0.01<P<0.05)$. Yet, in none of these strata were USA and Canadian abundance estimates significantly different. These results indicate that the depth differences in tow locations during the USA and Canadian surveys were not a major source of variability affecting the USA and Canadian abundance estimates.

\section{Size distributions}

Scallop shell-height frequencies from the USA and Canadian surveys in 1982-84 are presented by stratum in Fig. 3-5. In nearly all cases, the size frequency patterns of USA and Canadian data are similar. Both the USA and Canadian survey gears tend to effectively retain scallops after individuals have attained a size of $30-40 \mathrm{~mm}$ shell height (i.e. scallops in their third year of life). Incoming recruitment to the commercial fishery can thus be assessed from the survey data at least 1-2 years in advance.

The 1982 and 1983 data (Fig. 3 and 4) show little sign of above-average recruitment (i.e. a prominent mode between 30 and $60 \mathrm{~mm}$ ). Only the modal peaks at about $40 \mathrm{~mm}$ in strata 62 (USA only), 64 and 65 of the 1983 surveys (Fig. 4) indicate incipient recruitment. In 1984, however, both USA and Canadian surveys caught large numbers of prerecruit scallops in strata $62,63,64,65$, and 66 (Fig. 5), implying the production 

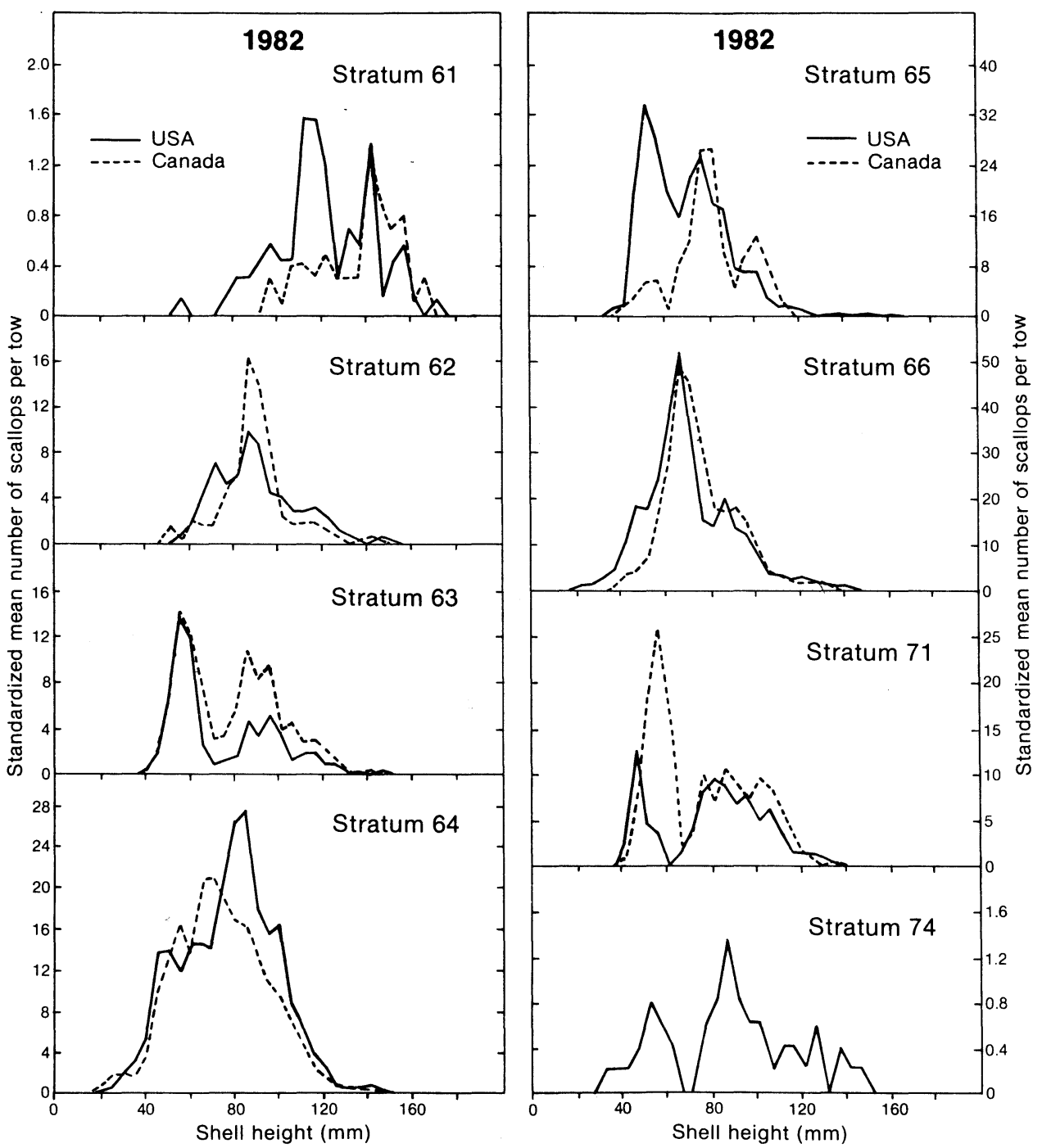

Fig. 3. Shell-height distributions of sea scallops by stratum from USA and Canadian surveys on northeastern Georges Bank in 1982. (Canadian data were standardized to USA tow distance equivalents.)

of an outstanding 1981 year-class. Overall prerecruit abundance indices for USA and Canadian surveys in 1984 (293.8 and 283.9 respectively) (Table 3) were 4 to 7 times higher than the corresponding 1982 and 1983 prerecruit indices. For both surveys in 1984, abundance indices of prerecruit scallops in stratum 64 $(>1,000$ scallops/tow) were about 10 times higher than during the preceding 2 years (78-114 scallops/tow). Examination of the size distributions and catch-pertow estimates from both the USA and Canadian surveys implies that recruitment, and hence abundance of scallops, tends to be localized and greatest on the most northeasterly part of the Bank (strata 64, 65, and 66).

Stratum comparisons of USA and Canadian shellheight frequencies indicated statistically significant $(P<0.05)$ differences in half of the 24 two-sample tests that were performed with the 1982-84 survey data
(Table 5). Differences were detected between USA and Canadian size distributions in three strata in 1982, four strata in 1983 and five strata in 1984. USA and Canadian results were statistically different in strata 66 and 71 in all 3 years. Other differences in size frequencies were inconsistent over time, occurring in one year but not in another. Moreover, the nature of the differences was not consistent. For example, in stratum 66, the USA survey caught a higher proportion of smaller scallops than the Canadian survey in 1982 and 1983 but not in 1984 (Fig. 3-5). Likewise, although USA and Canadian size distributions in stratum 65 were different in both 1982 and 1984, the cumulative frequency of small scallops in the USA survey in 1982 accounted for the difference, whereas the Canadian catches of small scallops in 1984 resulted in the distributions being statistically significant. Because the KolmogorovSmirnov two-sample test ( $\mathrm{K}-\mathrm{S}$ test) used in testing the 

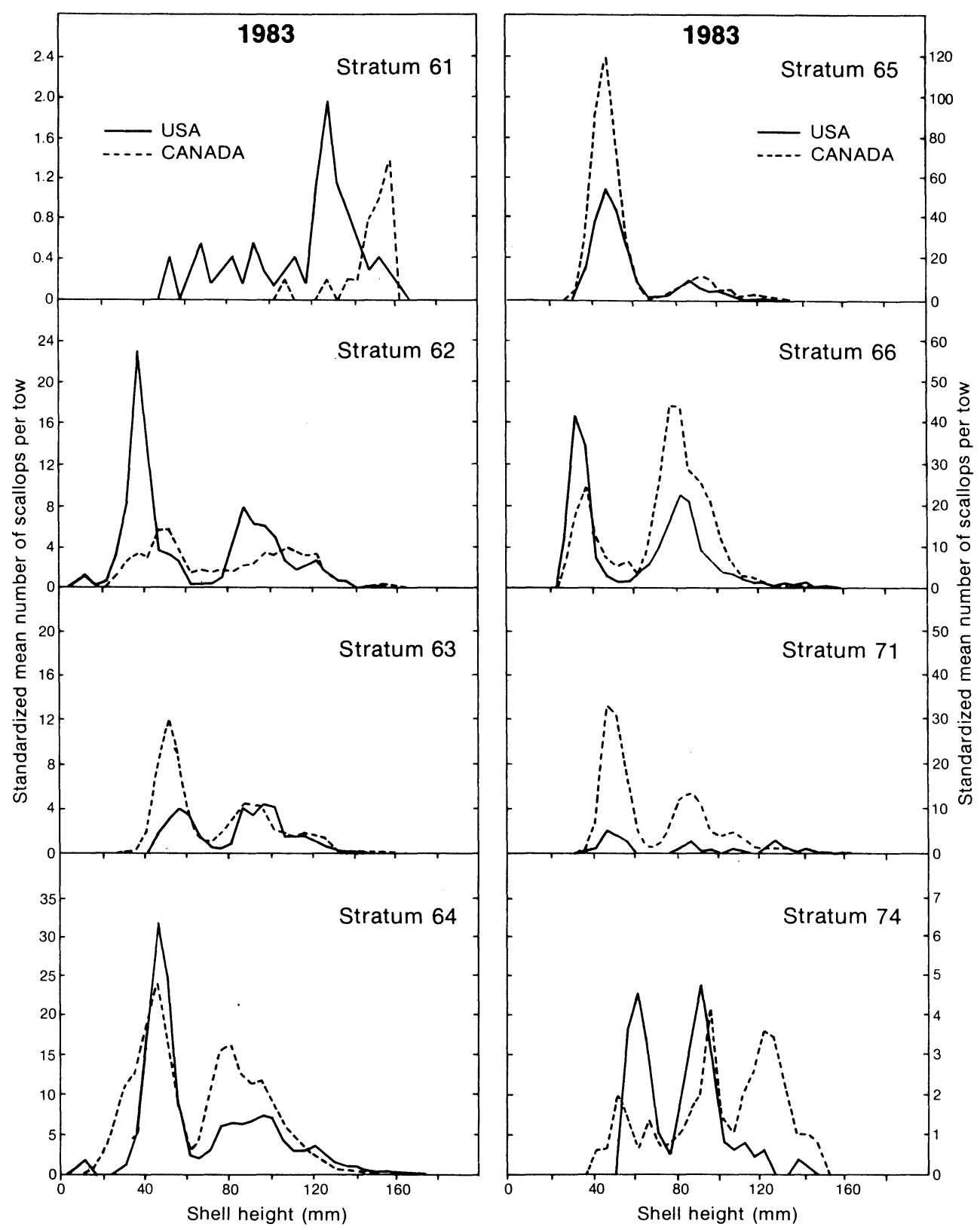

Fig. 4. Shell-height distributions of sea scallops by stratum from USA and Canadian surveys on northeastern Georges Bank in 1983. (Canadian data were standardized to USA tow distance equivalents.)

differences between the USA and Canadian size distributions only considers the largest differences between two distributions (Sokal and Rohlf, 1981), statistically significant differences can result which are not biologically meaningful. This is illustrated in Fig. 6 which depicts, for northeastern Georges Bank, sea scallop size distributions and cumulative distributions from the USA and Canadian surveys in 1982-84. The K-S test results for 1982 and 1983 indicated no significant difference between USA and Canadian size distribu- tions, but a highly significant difference $(P<0.01)$ between the two survey distributions was obtained in 1984. Visual scrutiny of the USA and Canadian distributions in 1984 (Fig. 6A) shows prominent modes of about equal magnitude (representing the 1981 cohort) in both surveys, but the modes are about $10 \mathrm{~mm}$ apart ( $37 \mathrm{~mm}$ in the Canadian survey and $47 \mathrm{~mm}$ in the USA survey). For such young, rapidly-growing scallops, the difference in modes has little, if any, biological meaning. Hence, although the USA and Canadian distribu- 

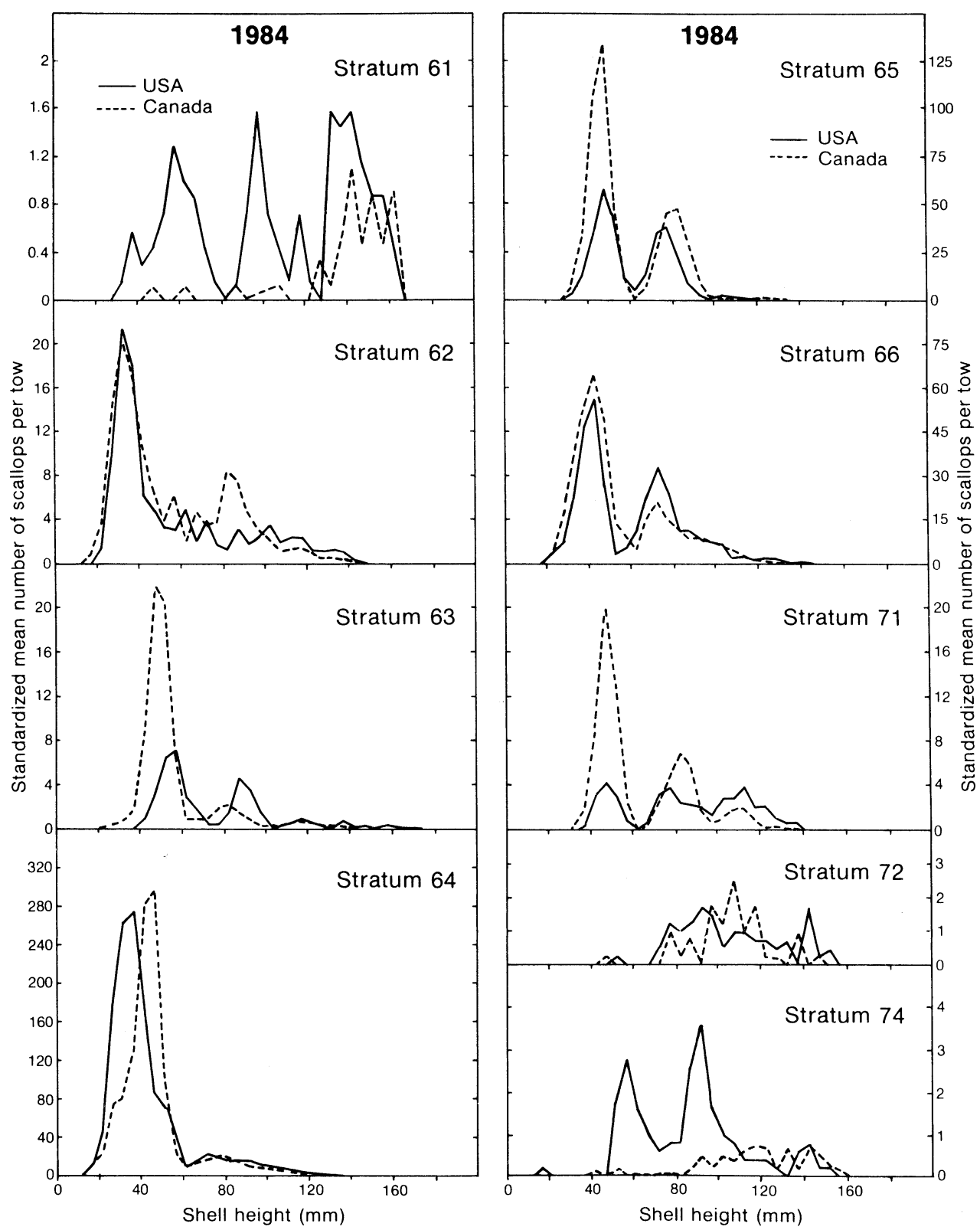

Fig. 5. Shell-height distributions of sea scallops by stratum from USA and Canadian surveys on northeastern Georges Bank in 1984. (Canadian data were standardized to USA tow distance equivalents.)

tions in 1984 differ statistically, this difference has limited external validity and, pragmatically, seems of little relevance.

\section{Discussion}

Comparative analyses of USA and Canadian sea scallop data from independent summer surveys of the northern edge and peak region of Georges Bank in 1982-84 indicate a high degree of concordance between the data sets. Statistically comparable esti- mates of relative abundance, recruitment levels and size composition were obtained from both surveys in all 3 years. In view of the different survey designs and sampling intensities, why were the results so similar? Several factors can be identified that may contribute to the concordance of the results.

1. Survey design differences may be more apparent than real. Although stratification of the USA and Canadian surveys is based on different variables (depth and commercial CPUE respectively), neither survey uses strictly proportional sampling. 

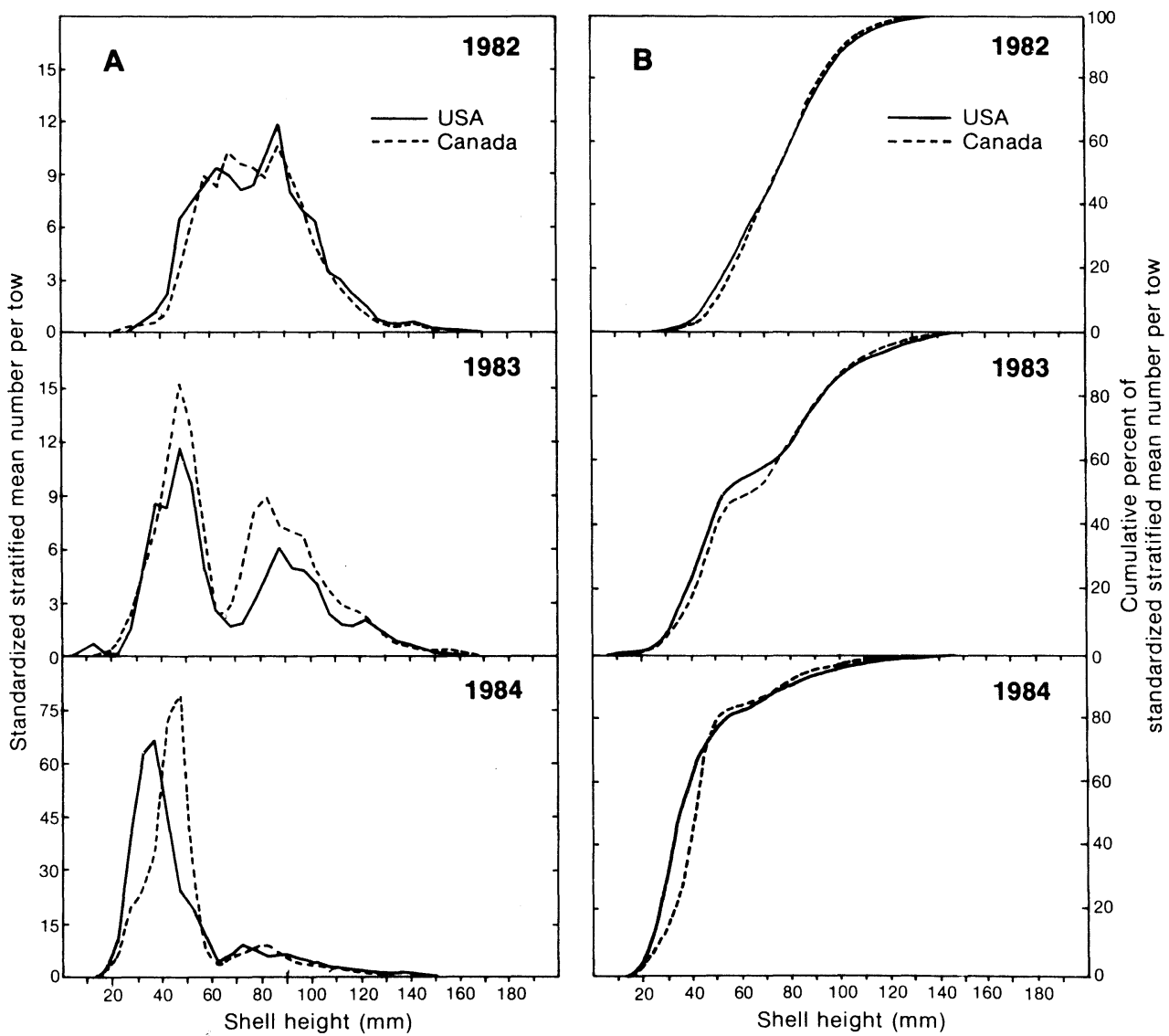

Fig. 6. Stratified (i.e. weighted by stratum area) shell-height distributions of sea scallops for the northeastern Georges Bank (A) and cumulative percent shell-height frequencies (B), from USA and Canadian surveys in 1982-84. (Canadian data were standardized to USA tow distance equivalents.)

In the USA survey, additional randomly selected sampling stations are frequently placed in strata for which prior information exists on fishing effort and/or scallop concentrations. In the Canadian survey, sampling intensity is extremely disproportionate with respect to stratum areas. Presumed areas of greatest scallop abundance are sampled with very high intensity. For example, in the 1983 Canadian survey, $40 \%$ of the total sampling stations were assigned to the "high" CPUE strata which comprised only $12 \%$ of the total survey area (Robert and Jamieson, 1986). As a consequence of these adjustments, the largest number of tows in both the USA and Canadian surveys tended to be allotted over the same general geographical area. The random assignment of tows within strata made the distributional array of USA and Canadian sampling stations within these areas nearly similar (see station locations in strata 63,64 and the easterly portions of strata 65 and 66) (Fig. 2). Resultingly, with the use of similar survey gears, comparable abundance indices and size compositions were obtained from both surveys.
2. Variance differences in abundance estimates by stratum are not considered in survey designs. Neither the USA nor the Canadian survey design is optimal in the sense of efficiently allocating sampling stations to reduce the variance in stratum abundance estimates. Indices of variability (standard deviation and coefficient of variation), associated with individual stratum mean catch-per-tow values, were relatively high in both the USA and Canadian surveys and exhibited a wide range among strata, both within and between years. Although differential catchability associated with bottom type and scallop density may be a cause of this variation, the problem is not addressed in the sampling design of either survey. Hence, the comparability of USA and Canadian survey results may reflect imprecision in discriminating all but the most extreme differences in USA and Canadian mean catch-per-tow values, e.g. fivefold differences in stratum 71 catch-per-tow values in 1983 (Table 4).

\section{Historically low stock levels in 1982-84 may have}


hampered the detection of differences in USA and Canadian survey results. Sea scallop aburidance on northeastern Georges Bank was at a recordlow level during 1982-84. Both USA and Canadian survey indices in these years were the lowest in their respective time series. Also, both USA and Canadian commercial catch rates during the period reached their lowest levels on record (Mohn et al., MS 1985; Serchuk and Wigley, MS 1986). In view of the poor condition of the scallop resource throughout the region, the likelihood that significantly different results could occur between the USA and Canadian surveys seems remote. Conversely, the increase in abundance of prerecruit scallops in 1984 (i.e. the 1981 year-class) was so large that both surveys would be expected, with a modicum of sampling intensity, to similarly detect this change.

4. Scallop patches remain in the same general geographical locality over time. Examination of spatial distributions of sea scallop concentrations from the extended time series of USA (1975-84) and Canadian (1977-84) surveys corroborates the observation that scallop patches (cohorts) "show up year after year in the same general location" (Robert et al., MS 1982), even though the patches are thinned down by the fishery. New patches arise from recruitment and existing patches become less distinct due to fishery removals. Success in sampling these patches is facilitated in the Canadian survey by stratifying on commercial CPUE (a proxy measure of patch distribution and density), derived from the fishery during the 11 month period before the survey. It is probable, however, that patches which produced high CPUE values even a month or two prior to the survey would be of minor importance at the time of the survey. Hence, the Canadian survey may be no more likely to sample extant patches of sea scallop than the USA survey in which sampling is based on preset strata areas. Mean catch-per-tow values for the four CPUE strata that were sampled during the Canadian survey of 1983 indicate that this is the case. The highest value was obtained from the "low" CPUE stratum (172 scallops/tow), whereas the "high", "medium" and "very low" CPUE strata had catch-per-tow values of 112, 69 and 69 respectively (Mohn et al., MS 1985). These findings imply that the correspondence between USA and Canadian survey indices results from similar probabilities in encountering scallop beds.

Irrespective of the factors that are actually responsible for the concordance of the USA and Canadian survey results, the information from the surveys appears to be the same. In this sense, the surveys are redundant. Because ship time involved with these surveys is costly, it might be prudent to consider alternative-year coverage of the Georges Bank scallop resource by the USA and Canada. The present analyses indicate that there would be virtually no loss in accuracy or precision by sharing the survey responsibilities, and a considerable saving of expense would ensue to both countries.

\section{Acknowledgements}

We thank Michael Fogarty of the Northeast Fisheries Center, Woods Hole, for constructive advice and suggestions on data analyses, and Vaughn Anthony of the Center for his review of the manuscript. Special gratitude is expressed to Ginette Robert, Invertebrates and Marine Plants Division, Canadian Department of Fisheries and Oceans, Halifax, Nova Scotia, for kindly providing copies of logsheets of the Canadian sea scallop surveys in 1982-84.

\section{References}

COCHRAN, W. G. 1977. Sampling techniques (3rd edition). John Wiley and Sons Inc., New York, N. Y., 428 p.

HALLIDAY, R. G., and P. A. KOELLER. 1981. A history of Canadian groundfish trawling surveys and data usage in ICNAF Divisions 4TVWX. Can. Spec. Publ. Fish. Aquat. Sci., 58: 27-41.

JAMIESON, G. S., and R. CHANDLER. MS 1980. The potential for research and fishery performance data isopleths in population assessment of offshore, sedentary, contagiously-distributed species. Can. Atl. Fish. Sci. Adv. Committee Res. Doc., No. 77, 32 p.

JAMIESON, G. S., M. J. LUNDY, G. L. KERR, and N. B. WITHERSPOON. MS 1981. Fishery characteristics and stock status of Georges Bank scallops. Can. Atl. Fish. Sci. Adv. Committee Res. Doc., No. 70, 40 p.

MOHN, R. K., G. ROBERT, and D. L. RODDICK. MS 1984. Georges Bank scallop stock assessment, 1983. Can. Atl. Fish. Sci. Adv. Committee Res. Doc., No. 12, 28 p.

MS 1985. Georges Bank scallop stock assessment, 1984. Can. Atl. Fish. Sci. Adv. Committee Res. Doc., No. 36, $24 \mathrm{p}$.

PENNINGTON, M. R., and M. D. GROSSLEIN. MS 1978. Accuracy of abundance indices based on stratifiedrandom trawl surveys. ICNAF Res. Doc., No. 77, Serial No. 5264, 42 p.

ROBERT, G., and G. S. JAMIESON. 1986. Commercial fishery data isopleths and their use in offshore sea scallop (Placopecten magellanicus) stock evaluations. Can. Spec. Publ. Fish. Aquat. Sci., 92: 76-82.

ROBERT, G., G. S. JAMIESON, and M. J. LUNDY. MS 1982. Profile of the Canadian offshore scallop fishery on Georges Bank, 1978-1981. Can. Atl. Fish. Sci. Adv. Committee Res. Doc., No. 15, 33 p.

SERCHUK, F. M. MS 1983. Results of the 1983 USA sea scallop research vessel survey: distribution and abundance of sea scallops in the Georges Bank, Mid-Atlantic, and Gulf of Maine regions and biological characteristics of Iceland scallops off the coast of Massachusetts. U.S. Nat. Mar. Fish. Serv., Northeast Fisheries Center, Woods Hole, 
Lab. Ref. Doc., No. 83-37, 54 p.

SERCHUK, F. M., and R. J. SMOLOWITZ. MS 1980. Size selection of sea scallops by an offshore survey dredge. ICES C.M. Doc., No. K:24, 38 p.

SERCHUK, F. M., and S. E. WIGLEY. MS 1984. Results of the 1984 USA sea scallop research vessel survey: status of sea scallop resources in the Georges Bank, Mid-Atlantic, and Gulf of Maine regions and abundance and distribution of Iceland scallops off the southeastern coast of Cape Cod. U.S. Nat. Mar. Fish. Serv., Northeast Fisheries Center, Woods Hole, Lab. Ref. Doc., No. 84-34, 74 p.

MS 1986. Status of the sea scallop resources off the northeastern United States, 1986. U.S. Nat. Mar. Fish. Serv., Northeast Fisheries Center, Woods Hole, Lab. Ref.
Doc., No. 86-08, 36 p.

SERCHUK, F. M., P. W. WOOD Jr., and R. S. RAK. MS 1982. Review and assessment of the Georges Bank, MidAtlantic, and Gulf of Maine Atlantic sea scallop (Placopecten magellanicus) resources. U.S. Nat. Mar. Fish. Serv., Northeast Fisheries Center, Woods Hole, Lab. Ref. Doc., No. 82-06, 132 p.

SERCHUK, F. M., P. W. WOOD, J. A. POSGAY, and B. E. BROWN. 1979. Assessment and status of sea scallop (Placopecten magellanicus) populations off the northeast coast of the United States. Proc. Natl. Shellfish. Assoc., 69: 161-191.

SOKAL, R. R., and F. J. ROHLF. 1981. Biometry (2nd edition), W. H. Freeman and Co., San Francisco, Calif., 859 p. 
